\title{
Respons Of Islamic Stock Markets To Monetary Policy Empirical Evidence from Indonesia
}

\author{
Muhammad Rasyidin', Zunaidah Sulong2 \\ 1,2Universiti Sultan Zainal Abidin, Malaysia \\ m_rasyidin@yahoo.com
}

\begin{abstract}
Purpose - The impact of stock market and capital formation on economic growth in Indonesia for the period of January 2015 - May 2019. This paper examines a long-run equilibrium relation between stock market, capital formation and economic growth and other control variables.
\end{abstract}

Method - This study uses autoregressive distributed lag (ARDL) model.

Result - Findings revealed that none of the models was stationary at level but were all stationary at first difference. There is not a short run significant relationship between stock market, capital formation and economic growth in Indonesia. In the long run, capital formation has a significant positive association on economic growth and a negative non-significant relationship between stock market and economic growth in Indonesia.

Implication - This research is useful to know the response of Sharia market to monetary policy instruments in Indonesia so that the Sharia stock market strategy is potentially developing in the future to encourage the achievement of characteristics such as An alternative source of financing and investment for economic actors and able to facilitate risk mitigation needs for market participants and able to drive the efficiency of transactions in the market through the improvement of the quality of stock marketinfrastructure Sharia.

Originality - The update of this research is response of Sharia stock market response to monetary policy instruments in Indonesia that are researched using ARDL models.

Keywords: $\quad$ stock market; money supply; exchange rate; inflation; interestrate. 
Muhammad Rasyidin, Zunaidah Sulong

\section{Introduction}

The liberalization and complexity of financial market instruments eases the flow of capital flows between countries. The free flow of capital will increase the global capital allocation that allows the transfer of resources from one country to another, especially from developed countries to emerging countries such as Indonesia. One of the causes of foreign capital flows from Indonesia due to global economic uncertainty. Global economic turmoil impacts the performance of financial markets, particularly the performance of the stock market. The stock market suffered pressure in line with the widespread trend in emerging financial markets. This global turmoil triggered volatility and increased capital outflow thus making the low value of shares. The occurrence of capital outflow due to the market reacts and will result in depreciation of the rupiah.

Capital inflow is highly dependent on the economic condition of a country. If the country's economy is in good condition, then the capital flows will go in so that the demand for the currency will increase and the value of the exchange will also strengthen. However, if the economy in the condition is not good, then the investor will move his funds (capital outflow) to the country whose economic condition is relatively stable so that the foreign currency will increase and the value of the domestic currency will weaken. Therefore, the flow of entry into the stock market should not be ignored by any country because it contributes positively to the country's economy (Beck \& Levine, 2004 and Pan \& Mishra, 2018). To anticipate this, the government through Bank Indonesia (BI) focuses on monetary policy that leads to prostability such as benchmark interest policy, inflation control, and exchange stability.

The stabilization of rupiah exchange rate is done to encourage more efficient market mechanisms. To maintain the stability of the Rupiah exchange rate in the market, $\mathrm{BI}$ took policy by raising the benchmark rate of BI 7-Day Reverse Repo Rate (7-Day RRR) from 4.25\% to 6.00\%. The rate of the benchmark is to anticipate The effects of The Fed's monetary policy 
normalization. The interest rate policy will continue to be adapted to the development of domestic and global economies to stabilize the rupiah exchange rate and its control over the inflation rate. Stability of inflation shows that Indonesia's economic fundamentals are getting better. This is evidenced by decreasing the inflation rate of 2018 by $3.13 \%$ compared with the year 2017 reaches $3.61 \%$ (yoy) and this condition is expected to be the appeal of investors to invest in the Indonesian stock market especially the market Sharia stocks.

Sharia stock market performance is also influenced by the uncertainty of the global stock market as a impact of the slowdown of the United States economy. Nevertheless, the sharia stock market in Indonesia is improving. It is evidenced by the positive movements of the Jakarta Islamic Index (JII) index in January 2019 reached the level of 727.01 points. In addition, in terms of number of investors also experienced an increase of reaching 50,500 investors at the first quarterly, when compared with the year 2018 only 44,536 investors and this is predicated will continue to increase with a target of at least $92 \%$ to the end years. Therefore, the Sharia stock market must have a strategic development in the future in order to encourage the achievement of characteristics such as alternative sources of financing and investment for economic actors and able to facilitate risk mitigation needs for market participants and able to drive the efficiency of transactions in the market through the improvement of the quality of the Sharia stock market infrastructure.

Sharia stock markets can be influenced by monetary change. Monetary policy has a major influence on the stock market (Suhaibu., Harvey \& Amidu, 2017). Monetary policy also has relation to price stability, such as supervision on the level of stability of the interest rate (Bong-Soo, 1992), Target inflation (Svensson, 1997), the amount of money supply (Yoshino., et., al., 2014). In theory that interest rate, inflation, money supply and exchange rates is considered as the main indicator of return and the source of stock market volatility (Ozbay, 2009). There are three channels related to the transmission of monetary policy both to the goods market and to the capital market 
namely the interest rate channel, the exchange rate, and the rate of inflation (Yoshino., Taghizadeh-Hesary., Hassanzadeh \& Prasetyo, 2014). These channels can affect stock markets, such as exchange rate changes (Yusof \& Majid, 2007 and Pratama \& Azzis, 2017), Inflation rate (primary \& Azzis, 2017) and money supply (Bahloul., Mroua and Naifar, 2017). Monetary policy proved to be an important element in the economic cycle phase (Ghazali \& Yakob, 1998) such as the economic slowdown (slowdown), economic recession (recession), economic recovery (recovery) and economic expansion (exspansion/Boom).

In slowdown phase the economic activity weakened and the high inflation pressure had to be anticipated with rising interest rates. Position of stock in bearish condition due to weakening of economic growth and lack of profit of the company. While stock positions are bullish, because interest rates are experiencing an increase and this makes investors switch savings or deposits. The conditions of the recession interest rates are decreasing, the profit of the company also decreases, so that the investor prefers obligation, although the stock market can also be used as an alternative to invest because of the performance of stocks began to rebound. The recovery phase of this interest rate decreased, while stock prices tended to rise and bullish. The inflation-related phase tends to increase due to rising interest rates. Stock performance again outperform bonds as the company's potential profit increases, supported by high demand and strong consumer purchasing power.

\section{Literature Review}

The stock market responds to the instruments of monetary policy, such as the amount of money supply and inflation responds positively to the stock market shocks, while interest rates respond negatively to the stock market. (Suhaibu, at, al. 2017). El-Hasanah \& Panjawa (2016) in his studies said that before the global monetary crisis the exchange rate negatively affects Jakarta Islamic Index (JII), while the inflation rate and amount of money supply has no effect on JII. After the global monetary crisis the exchange rate and 
inflation have no significant effect on JII, while the money supply significantly has a positive influence on JII. But Yoshino., et, AL., (2014) says that the amount of money supply will negatively affect the stock price if the change in the amount of money circulating is related to the increase and uncertainty of future inflation (Yoshino., et., al., 2014).

Interest rates are the most widely used monetary instrument in the policy (Bong-Soo, 1992), as the interest rate changes negatively impact and significant return on shares (Kasman, Vardar and Tunc, 2011). Stock market interest rates have a negative correlation with interest rates. The high interest rate caused by the contracted monetary policy eventually negating the return of the stock. High interest rates can reduce the value of equity (dividend discount model) and this makes investors reduce their investment in the stock market. On the other hand, low interest rates are also the result of an expansive monetary policy that tends to drive the stock market. Stock market volatility is affected by the inflation rate (Ozbay, 2009 \& Kasman, Vardar and Tunc, 2011).

Globalization and trade liberalization cause the exchange rate to have a relationship either directly or indirectly with the stock market (Bala \& Hassan, 2018). The Sharia stock market is influenced by the exchange rate (Yusof \& Majid, 2007 and Pratama \& Azzis, 2017). A very strong exchange rate is a strong and viable signal of economic strength. While on the other hand a very weak currency is a reflection of a very vulnerable and weak economy. The instability of the exchange rate has a real economic shock as it negatively impacts the price level (Adamu, Mika'ilu and Umar, 2017). ElHasanah \& Panjawa (2016) in his studies said that before the global monetary crisis the exchange rate negatively affects Jakarta Islamic Index (JII). After the global monetary crisis the exchange rate does not affect JII. Abdalla \& Murinde (1997) has interacted exchange rates with the stock market in four countries, namely India, Korea, Pakistan, and the Philippines. His study shows that there is a direct link between the exchange rate and the stock market in all countries. Stock market volatility is influenced by the exchange rate and 
Muhammad Rasyidin, Zunaidah Sulong

inflation (Ozbay, 2009) It proves that the stock market is a call for every monetary policy change.

\section{Methods}

The data used in this study is monthly secondary data in the form of time series from January 2015 - May 2019. The Sharia stock market is represented by Jakarta Islamic Index (JII), and the instrument of monetary policy in the form of money supply, exchange rate, inflation and interest rates by using est root unit before the model estimation. The root unit test needs to be done given the characteristic of Skokastic data time series. This test also detects whether it is stationary at a level or I ( 0 ) on all research variables. If all of these variables are stationary in I (0), then the stationery test will be done on first difference or I (1).

The Model used in this study was Autoregressive Distrubuted Lag (ARDL). Use of this model is due to the majority of macroeconomic data tends to be not statisioner at the level or I ( 0 ) due to structural changes. In this study also determine the maximum lag of the integration test used Akaike Information Criteria (AIC) and the Schwarz's Bayesian Information (SB). In ARDL model testing the classic assumption of the model. To clarifys Autoregressive Distrubuted Lag (ARDL) cointegration test, the Sharia stock market model and monetary policy in Indonesia. All variables will be transformed in logarithmic (Ln) Form except variable interest rate (IR) and inflation (INF).

To test long run equilibrium, the model used is as follows.

$$
J h_{z}=\alpha+\beta_{1} U B_{t-1}+\beta_{2} \text { Kurs }_{t-1}+\beta_{3} I R_{t-1}+\beta_{4} I n f_{t-1}-
$$

The long-term models are the reduce fom of the short-term ARDL-ECM models that will be estimated in this study as follows: 
Where $\alpha$ is the intercept, $\beta 1$ to $\beta 4$ is the slope koefisein of the explosive varaibel and $\varepsilon$ is the error term. In this model Sharia stock market was proscribed with Jakarta Islamic Index (JII), Money Supply (UB), Exchange Rate, Interest Rates (IR), and Inflation (INF). Ln JII is a Log of Jakarta Islamic Index, Ln UB is a Natural logarithm of money supply and Ln money exchange

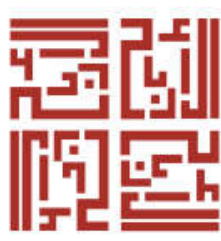
is logarithm natural of the exchange rate.

\section{Discussion}

In Autoregressive Distributed Lag (ARDL) method,the root unit test is not mandatory, but it is well done to ensure that the data used is no stationary at the second difference level or I (2). In this study a test of the root unit was carried out with Augmented Dickey-Fuller (ADF) and Phillips - Perron (PP) tests. The test root unit can be seen in table 1.

Table. 1: ADF and PP root unit test results

\begin{tabular}{cccccc}
\hline \multirow{2}{*}{ Model } & Variable & \multicolumn{2}{c}{ ADF Test Statistic } & \multicolumn{2}{c}{ PP Test Statistic } \\
\cline { 3 - 6 } & Intercept & $\begin{array}{c}\text { Trend and } \\
\text { Intercept }\end{array}$ & Intercept & $\begin{array}{c}\text { Trend and } \\
\text { Intercept }\end{array}$ \\
\hline \multirow{2}{*}{ Level } & Ln_JII & -1.903 & -1.985 & -2.091 & -2.182 \\
I(0) & Ln_UB & -1.369 & $-5.393^{* * *}$ & -0.618 & -5.626 \\
& Ln_Kurs & -2.501 & -2.715 & -2.467 & -2.715 \\
& IR & -1.903 & -0.179 & -1.610 & -0.548 \\
\hline \multirow{2}{*}{ 1st } & Inf & $-2,009$ & $-1,687$ & -2.017 & -1.840 \\
Different & Ln_JII & $-6.483^{* * *}$ & $-6.416^{* * *}$ & $-6.481^{* * *}$ & $-6.414^{* * *}$ \\
I(1) & Ln_Kurs & $-6.140^{* * *}$ & $-6.310^{* * *}$ & $-16.562^{* * *}$ & $-16.459^{* * *}$ \\
& IR & $-8.112^{* * *}$ & $-8.047 * * *$ & $-8.162^{* * *}$ & $-8.094^{* * *}$ \\
& Inf & $-5.199 * * *$ & $-5.479^{* * *}$ & $-5.312^{* * *}$ & $-5.540^{* * *}$ \\
\hline
\end{tabular}

$*, * *$, and $* * *$ is the significance to $10 \%, 5 \%$ and $1 \%$. 
Muhammad Rasyidin, Zunaidah Sulong

Table 2: Results of Diagnostic Tests

\begin{tabular}{ccc} 
Serial Correlation & Normality & Heteroscedasticity \\
\hline 1.773 & 0.628 & 0.458 \\
{$[0.128]$} & {$[0.730]$} & {$[0.766]$} \\
\hline
\end{tabular}

the mark [ ] is p-value.

Table 1 shows that the root unit test is based on the ADF and PP test at level or I (0) various stationary (a mix of stationarities) and all stationary variables in first difference or I (1). It can be stated that it meets the criteria for using ARDL technique.

The diagnostic test results displayed in table 2 indicate that all models have passed a diagnostic test. In the serial correlation testing using the Breusch-Godfrey Serial Correlation LM Test found that the model has no evidence of serial correlation. Whereas heterokeadastisity tests using the Breusch-Pagan-Godfrey model also showed no heteroskedasticity effects. In addition, the Jarque-Bera normality test shows that the faults of each model are distributed normally and all models are well-expressed as they are all probability values above $5 \%$.

Table 3: ARDL Bounds F-test

\begin{tabular}{ccc}
\hline Model & F-Statistic & k \\
\hline Economic Growth & $3.089^{* * *}$ & 4 \\
\hline Critical Value Bounds for F-Statistics & $\mathrm{I}(0)$ Bound & $\mathrm{I}(1)$ Bound \\
\hline $\mathbf{1 0 \%}$ & 2.45 & 3.52 \\
$\mathbf{5 \%}$ & 2.86 & 4.01 \\
$\mathbf{1 \%}$ & 3.74 & 5.06
\end{tabular}

$*, * *$, and $* * *$ is thesignificance to $10 \%, 5 \%$ and $1 \%$.

Table 3 shows the results of the F statistic ARDL bounds test for cointegration. Based on a maximum of 3 defined lag values (AIC) criteria, the value of the number is specified on each model. The critical value for the economic growth model below the number of variables is $\mathrm{k}=4$. The value of $\mathrm{F}$ statistics is above I (1) bounds of $3.08<3.52$, so it can be concluded that this research variable has no co integration in the long term. 
Table 4: Short Run Estimation

\begin{tabular}{|c|c|}
\hline Variable & Coefficient \\
\hline \multirow[t]{2}{*}{$\Delta \mathrm{Ln} \_\mathrm{UBt}$} & $0.187862^{* * *}$ \\
\hline & $(0.0003)$ \\
\hline \multirow[t]{2}{*}{$\Delta \mathrm{Ln} \_$Kurst } & $-0.982052^{* * *}$ \\
\hline & $(0.0000)$ \\
\hline \multirow[t]{2}{*}{$\Delta \mathrm{Ln} \_I n f t$} & -0.003513 \\
\hline & (0.1612) \\
\hline \multirow[t]{2}{*}{$\Delta \mathbf{R}$} & -0.010066 \\
\hline & (0.3089) \\
\hline \multirow[t]{2}{*}{$\Delta$ IRt-1 } & $-0.008647^{* * *}$ \\
\hline & (0.4964) \\
\hline \multirow[t]{2}{*}{$\Delta \mathrm{IRt}-2$} & -0.004249 \\
\hline & $(0.7385)$ \\
\hline \multirow[t]{2}{*}{$\Delta$ Rt-3 } & 0.017194 \\
\hline & $(0.0507)$ \\
\hline \multirow[t]{2}{*}{ CointEq t-1 } & $-0.440438^{* * *}$ \\
\hline & $(0.0003)$ \\
\hline
\end{tabular}

The short-term estimation results in table 4 appear to be a CointEq t-1 value of- 0.440438 with a prob of 0.0003 , means that there is a cointegration in the model. The negative CointEq beta value indicates that the model will be towards a balance with a speed of 44.04 percent per month.

The long-term estimation results show that the amount of money based on the Islamic stock market is positively and significantly influential. This suggests that the stock market responds positively to the money supply. The study was in accordance with the results of El-Hasanah \& Panjawa (2016) stating that after the global monetary crisis the amount of money was positively circulated against the sharia stock market. 
Muhammad Rasyidin, Zunaidah Sulong

Table 5: Long Run Estimation

\begin{tabular}{ll}
\hline Variable & Coefficient \\
\hline C & 9.253983 \\
Ln_UB & $(0.0008)$ \\
& $0.426534^{* *}$ \\
Ln_Kurs & $(0.273828)$ \\
& $-2.229716^{* * *}$ \\
INF & $(0.0004)$ \\
& -0.007976 \\
IR & $(0.2406)$ \\
& -0.003386 \\
\hline
\end{tabular}

Catatan: ${ }^{*}, * *$, and ${ }^{* * *}$ is the significance to $10 \%, 5 \%$ and $1 \%$.

The same is also found in the study of Alatiqi and Fazel, (2008) and Li (2012) who said that the money circulating in the short term affects the stock market. But the study contradictory to the findings of Yoshino., et., AL., (2014) said that the money supply is negatively affected by the share price. The exchange rate negatively and significantly affects the Sharia stock market. The results of this study supported the study conducted by El-Hasanah \& Panjawa (2016)

The research also supports the study of Adamu, et., AL, (2017) stating that the exchange rate affects the stock market. With the stability of the exchange rate will make the issuer's financial statements well, so as to make investors like the shares and the price of the company's share will be increased.

Inflation has a negative effect but not significant to the Sharia stock market. Controlled inflation will make stock prices more likely to rise. The weak rate will be negatively responded by the market so that the stock price will fall due to the massive selling action by the investor. Interest rates are negatively influential but not significant to the Sharia stock market. This research is in line with the study results of Kasman, et., al. (2011) which states that interest rate changes negatively affect the return of shares (Kasman, Vardar and Tunc, 2011). 
Respons Of Islamic Stock Markets To Monetary ...

\section{Conclusion}

This study examined the sharia stock market's response to monetary policy instruments in Indonesia using the ARDL model. The results concluded that the three variables of monetary policy were responded by the market in the long term (cointegration). Meanwhile, in the short-term relationship only money supply and the exchange rate is quick to be responded by the stock market.

\section{References}

Abdalla, Issam \& Murinde, Victor., (1997). Exchange Rate and Stock Price Interactions in Emerging Financial Markets: Evidence on India, Korea, Pakistan and the Philippines. Applied Financial Economics. 7(1): 25-35

Adamu, Hassan., Mika'ilu, Abubakar., \& Umar, Dantama Yusuf. (2017). Determinants of Exchange Rate Volatility: New Estimates from Nigeria. Eastern Journal of Economic and Finance. 3(1): 1-12

Alatiqi, Sara and Fazel, Shokoofeh. (2008). Can Money Supply Predict Stock Prices?. Journal for Economic Educators.

Al-Smadi, Mohammad. O. (2018). Determinants of foreign portfolio investment: the case of Jordan. Investment Management and Financial Innovations, 15(1), 328-336.

Ananwude, Amalachukwu Chijindu, dan Osakwe, Charity Ifunanya. 2017. Stock Market Development and Economic Growth in Nigeria: A Camaraderie Reconnaissance. Research Journal of Economics, 1(3), 16.

Bahloul, Slah., Mroua, Mourad \& Naifar, Nader. (2017). The Impact of Macroeconomic and Conventional Stock Market Variables on Islamic Index Returns Under Regime Switching. Borsa Istanbul Review. 17(1): $62-74$

Bala Sani AR and Hassan A. (2018). Exchange Rate and Stock Market Interactions: Evidence from Nigeria. Arabian Journal of Business and ar A Management Review. 8(1): 3-5

Beck, T. and Levine, R. (2004). Stock Markets, Banks, And Growth: Panel Evidence. Journal of Banking \& Finance, 28(3): 423-442 
Muhammad Rasyidin, Zunaidah Sulong

Bong-Soo, L. (1992). Causal Relations among Stock Returns, Interest Rates, Real Activity, and Inflation. Journal of Finance. 47(4); 1591-603.

El-Hasanah, Lak lak Nazhat \& Panjawa, Jihad Lubis. (2016). The Effectiveness of Monetary Policy Towards Stock Index Case Studi : Jakarta Islamic Index 2006-2014. Jurnal Ekonomi Pembangunan, 17(1): 100-107

AL-ARBAH | 46 Kasman, Vardar dan Tunc. (2011). The impact of interest rate and exchange rate volatility on banks' stock returns and volatility: Evidence from Turkey". Economic Modelling, (28): 1328-1334

Li, Yijun. (2012). Empirical Study on the Relationship between Money Supply and Stock Market in Europe. International Conference on Information Computing and Applications. 539-544

Ozbay, E. (2009). The Relationship Between Stock Returns And Macroeconomic Factors: Evidence For Turkey. Devon, University of Exeter, Financial Analysis and Fund Management, Yayınlanmamış Yüksek Lisans Tezi, Master of Science Thesis

Pan, Lei dan Mishra, Vinod. 2018. Stock Market Development and Economic Growth: Empirical evidence from China. Economic Modelling. 68: 661673

Pratama, Yoghi Citra \& Aziz, Abdul. (2018). Macroeconomic Variables, International Islamic Indices, and The Return Volatility in Jakarta Islamic Index.Al-Iqtishad: JurnallimuEkonomiSyariah Journal of Islamic Economics). 10(1): 171-188

Suhaibu, Iddrisu., Harvey, Simon K \&Amidu, Mohammed. (2017). The Impact of Monetary Policy on Stock Market Performance: Evidence from Twelve (12) African Countries. Research in International Business and Finance. 42(C): 1372-1382

Svensson, Lars E O (1997) Inflation Forecast Targeting: Implementing and Monitoring Inflation Targets. European Economic Review. 41(6): 1111- 1146

Yoshino, Naoyuki., Taghizadeh-Hesary, Farhad., Hassanzadeh\&Prasetyo, Ahmad, (2014). Response of Stock Markets to Monetary Policy: An Asian Stock Market Perspective. Macroeconomics Working Papers. East Asian Bureu of Economic Research

Yusof, Rosylin Modh\& Majid, M. ShabriAbd. (2007). Macroeconomic Variables and Stock Returns in Malaysia: An Application of The ARDL Bound Teting Approach. Savings and Development. 31(4):449-469 